\title{
Sciendo
}

\section{HOW MONETARY POLICY AFFECTS THE LENDING AND ECONOMIC ACTIVITY IN A BANKING SYSTEM WITH EXCESS LIQUIDITY}

\author{
Dashmir Saiti $^{1}$, Gjorgji Gockov ${ }^{2}$, Borce Trenovski ${ }^{3}$ \\ ${ }^{1,2,3}$ Ss. Cyril's and Methodius University, Faculty of Economy, Republic of North Macedonia \\ 11dashmirs@gmail.com, 20jorgji.gockov@eccf.ukim.edu.mk, ${ }^{3}$ borce.trenovski@eccf.ukim.edu.mk
}

Received 10 November 2021; accepted 30 November 2021

\begin{abstract}
Research purpose. The purpose of this paper is to examine the efficiency of the transmission mechanism of the monetary policy in a banking system with excess liquidity. More specifically, it aims to examine how the interest rates of the central bank bills and inflation rate affect total lending and the overall economic activity in the country. For this purpose, the analysis is based on the case of the Republic of North Macedonia, whose banking system has exhibited excess liquidity in the past decade.
\end{abstract}

Design / Methodology / Approach. The paper is based on two different VECM models, analyzing the impact of the central bank bills interest rates and the inflation rate, on lending and real GDP in the Republic of North Macedonia, for the period 2000 - 2019. The analysis also encompasses unit root tests for the variables of interest in order to determine their order of integration and choose appropriate statistical methods. The short-run causality is assessed using the Granger causality test, whereas the existence of the potential long-run relationship is examined using the Johansen cointegration test. In addition, in order to determine the magnitude of the mutual relationship, variance decomposition is employed in both estimated models. Moreover, the stability of the models when exposed to external shocks is observed through their impulse response functions.

Findings. Conducted analysis shows the negative long-term impact of the central bank bills interest rates on lending and real GDP in North Macedonia. However, no statistically significant impact in this regard is found in the short run. Opposingly, the inflation rate negatively affects lending and real GDP in North Macedonia in the short run, whereas, in the long run, it does not have a statistically significant impact.

Originality / Value / Practical implications. Unlike many other studies in this area, this paper provides practical guidance for the monetary authorities in countries with excess liquidity in the banking system. Namely, its findings imply that central banks should reduce the interbank rate when faced with crises that cause liquidity disparities between banks. Failure to reduce interest rates during the crisis disrupts financial stability, which causes banks to withhold investing their liquid assets in the real economy.

Keywords: interest rates of the central bank bills, inflation, total lending, real GDP, monetary policy.

JEL codes: E43, E31, E51, E52.

Citation: Saiti, D., Gockov, G., Trenovski, B. (2021). Evaluation of key factor of digital economy in European Union. Economics and Culture, 18(2), 51-60. https://doi.org/10.2478/jec-2021-0014

\section{Introduction}

When the monetary policy is focused on maintaining Denar exchange rate stability, interest rates and money supply are dependent categories determined by the achievement of the intermediary objective. The research on the movement of interest rates on the central bank bills in North Macedonia during the Great Economic Crisis of 2008 and the economic recovery shows highinterest rates on central bank bills. The monetary policy in the Republic of North Macedonia 
(RNM) during and after the Great Economic Crisis was tight, with high-interest rates of central bank's bills (CB bills). In this regard, maybe we should consider harmonization of the monetary policy and reduction of external influences.

Interest rates of the CB bills are fundamental monetary policy indicators, in general as well as in North Macedonia specifically, especially in the post-crisis period. Namely, when the national economy was struggling to get out of the recession, high interest rates of CB bills, as passive interest rates, were tempting for investment by commercial banks in the country. Instead of pursuing an expansionary monetary policy, the National Bank of the Republic of North Macedonia (NBRNM) contributed to the withdrawal of excess liquidity of the commercial banks but did not direct it towards investing in the real economy. The National Bank, through its interest rate policy, sends monetary signals to commercial banks and thus, tends to influence their lending and deposit interest rates. Implementing such monetary strategy in conditions of a structural surplus of liquidity made be CB bills auction the main instrument of the monetary policy (an instrument used to withdraw instead to create liquidity in the banking system). Therefore, the interest rate achieved at the CB bills auctions is regarded as the key interest rate of the National Bank. According to Freixas, et al. (2011), central banks should reduce the interbank rate when faced with crises that cause liquidity disparities between banks. They also note that the failure to reduce interest rates during the crisis disrupts financial stability, which causes banks to withhold investing their liquid assets in the real economy.

The primary objective of the monetary policy in the RNM is to maintain price stability. NBRNM also supports the economic policy and the financial stability of the country, but without jeopardizing the accomplishment of its primary objective. For achieving its ultimate objective, NBRNM establishes an intermediary objective of the monetary policy. Since 1995 intermediary objective of the monetary policy has been the maintenance of the exchange rate stability (targeting the nominal exchange rate of the Denar against the Euro (prior 2002 against the Deutsche Mark)). Given that banks consider CB bills as an alternative instrument for placing their funds, the issue of the efficiency of the monetary policy transmission mechanism is particularly interesting for analysis.

The research subject measures the short-term and long-term effects of CB bills interest rates and inflation rate on total lending and real GDP in North Macedonia from 2000 to 2019. In this regard, it is assumed that CB bills interest rates, as well as the inflation rate, negatively affect total lending and real GDP, both in the short run and in the long run.

\section{Literature review}

According to the empirical analysis, there are different approaches to the analysis of financial activity and economic growth, i.e., the effects of CB bills interest rates and inflation on credit activity and economic growth. Schumpeter's (2017) development theory explains that bank loans play a crucial role in economic growth. They are defined as the aggregate equivalent of funds provided by commercial banks for the needs of individuals, business organizations, and governments' requirements. Credit, therefore, plays an essential role in the economic development of a country.

Levine (2004) reviewed theoretical and empirical work on the relationship between financial development and economic growth. He illuminates many of the channels through which the emergence of financial instruments, markets, and institutions affect - and are affected by economic development. Central to the debates is whether an economic activity can explain the growth of the financial sector or the development of the financial sector drives economic growth (Chandrashekar, et al., 2018). According to Karimo et al. (2017), the causal relationship between financial development and economic growth depends on the stage of economic development. Namely, they argue that in the early stages, the development of financial services positively affects economic growth through the creation of new financial services and opportunities, both for savers and investors. In other words, the demand-leading view dominates, alongside financial and economic development, while the supply-leading view is becoming less important. In addition, Levine (2004), through various studies and analogies, shows a strong positive relationship between the functioning of the financial system and long-term economic growth. 
On the other hand, economic growth, as well as the overall macroeconomic stability, also affect the financial sector in the country and its development. With respect to the influence of price stability on financial development, Ehigiamusoe et al. (2019) provide evidence that inflation negatively affects financial development in countries with high and medium inflation. Furthermore, Shijaku et al. (2013), using the VECM model based on supply and demand indicators for the case of Albania in the period 2001 - 2011, show that economic growth positively affects lending. In any case, the discussion in this regard only emphasizes the importance of the relationship between economic growth and financial development and its relevance for the overall economic development of the country.

One of the most crucial topics in monetary policy research is whether to focus on nominal or real terms (Barnett \& Su, 2019). The conclusion of classical economists is that nominal income is determined by the movement of money supply and relies on the assumption that the speed PY / $\mathrm{M}$ can be treated as reasonably constant (Bambujijumugisha, 2016). Irving Fisher developed the theory of the amount of money for transactions such as MV $=\mathrm{PY}$, where $\mathrm{M}$ is the currency and other forms of money in circulation (M1, M2, M3), i.e. M is defined as the amount of money, V is the velocity of money, $\mathrm{P}$ represents the price level and $\mathrm{Y}$ is the actual output, where the velocity of money (V) is fixed in this model, and it is stated that the nominal GDP (PY) is affected by any change in the money supply (Sultana, 2018). On the other hand, while "Monetarists" believe that monetary policy affects prices, but not real GDP, Keynesians argue that changes in the money supply led to changes in the real output and prices (Chaitipa et al., 2015).

There is a number of courses of action in which monetary policy gets transmitted to the real economy. The monetary transmission mechanism describes how policy-induced changes in the nominal money stock or the short-term nominal interest rate impact real variables such as aggregate output (Ireland, 2006). The central bank may have a more significant set of goals than just its primary goal of stabilizing inflation and stabilizing output (Capie \& Wood, 2016). Its primary function as a liquidity management instrument is to sell short-term securities by the central bank, whereby the interest rate is the basic interest rate that determines the monetary policy. According to Gonpot et al. (2010), higher interest rates make domestic assets more attractive than investments in other currencies and contribute to higher domestic currency demand.

On the other hand, lower domestic interest rates will cause cheaper domestic goods than foreign ones and an increase in net exports. However, lending is not only related to the CB bills interest rates but also to commercial banks' net worth, the risk level, level of the existing asset portfolio and regulatory constraints (Greenwald and Stiglitz, 2003). Nyawata (2013) discusses the challenging question of whether central banks should use central bank accounts to drain excess liquidity in the banking system. He notes that CB bills are the first best option because they have positive externalities in the financial sector and the rest of the economy. The three main pillars are operational independence of central banks, market development, and strengthening the transmission of impulses to monetary policy.

Monetary policy actions do not affect every country in the world equally. Willems's (2018), using VAR panel analysis for 162 countries for the period 1970-2017, shows that developing countries have greater price flexibility (monetary neutrality), while advanced economies show more significant price stickiness signs. According to his study, raising interest rates by 100 basis points in developed economies is associated with a reduction of real GDP by $0.5 \%$ against a $0.3 \%$ reduction in developing countries.

According to Olofinlade et al. (2020), monetary policy rate and inflation rate in Nigeria have insignificant influence on bank lending in the country. In addition, these two variables have a negative but also insignificant impact on the economic performance of the country, as well. Given the findings, the authors suggest facilitating regulatory and supervisory frameworks to secure a strong financial sector for efficient intermediation.

Similarly, Amidu (2006) also provide evidence that the central bank's prime rate and inflation rate have a negative but statistically insignificant impact on banks' lending for the case of Ghana for the period 1998-2004. He argues that economic activity in the country, as well as changes in the money supply, significantly affect banks' lending behavior. In another study for the case of Ghana, 
but for a more recent period (2002-2014), Akosah's (2015) examines the effectiveness of Ghana's monetary policy transmission, highlighting the prominent role of central bank bills in the Ghanaian interest rate transmission channel. The study concludes that short-term inflation has a more significant impact than the foreign exchange shock, while on the other hand, medium and long-term interest rate shocks mainly cause inflation.

The subject of the effectiveness of the monetary transition mechanism in countries with excess liquidity in the banking system (specifically North Macedonia) is also the main focus of interest for several North Macedonian researchers. Namely, Jovanovic et al. (2015) examine the real effects of several monetary policy instruments, whereby they primarily find that the interest rate channel does not have a strongly emphasized effect in North Macedonia. More specifically, they argue that economic activity in the country can be affected through the reserve requirement and offered amount of CB bills, which would have a diverse impact given the excess liquidity in the banking sector in North Macedonia. Similarly, Kabashi \& Suleva (2016) provide evidence of fairly limited effects of the monetary policy in North Macedonia on lending activity. Namely, they argue that landing rates are affected more than the loan volumes, which might be a relevant finding for the overall economic activity in the country.

Regarding the interest rate pass-through, Gigineishvili's (2011) finds that excess liquidity in the banking sector has an adverse impact, while the inflation rate positively affects it. These findings are based on a cross-sectional analysis covering low income, emerging and developed countries from all regions.

In line with the theoretical and empirical literature, the purpose of this paper is to examine the efficiency of the transmission mechanism of the monetary policy in the RNM as an example of a country with excess liquidity in the banking system. More specifically, the focus is on the impact that $\mathrm{CB}$ bills interest rates and the inflation rate have on total lending and the overall economic activity in the country.

\section{Methodology}

This research used quarterly data from the databases of the World Bank (WB) and the National Bank of the Republic of North Macedonia (NBRNM) for the period from 2000 to 2019. Originally, real GDP (in North Macedonian Denars) and inflation rate (in percentages, calculated based on the consumer price index) were taken from the WB database on an annual basis. Afterwards, GDP was transformed quarterly by breaking down annual data into average quarterly data. Quarterly inflation data is obtained by converting the frequency in the statistical software EViews using the cubic method, as used in most scientific papers, due to its integration of the polynomial function. CB bills interest rates were taken from the NBRNM database on a monthly basis, whereby they were also quarterly transformed by averaging them for the corresponding quarter. Similarly, total lending was also taken from the NBRNM database and transformed quarterly, only here instead of average; it was summarized on a quarterly level since it is expressed in absolute amounts (North Macedonian Denar) rather than in percentages.

Regarding the variable selection, it is important to emphasize in this point that CB bills, as used in the analysis, is not the same as treasury bills. Namely, the treasury bills are an instrument of the fiscal policy of the country, namely the Ministry of Finance, whereas, on the other hand, CB bills are an instrument of the monetary policy in the RNM. Therefore, these two are different instruments, that in a way, serve the same goal. However, the focus in this paper is on the CB bills interest rates.

In line with the empirical literature in this area (Calza et al., 2001), the research was founded on two econometric models based on the vector error correction mechanism (VECM) model approach. In the first model (VECM_1), the natural logarithm of the total lending (LCREDIT) is taken as a dependent variable, whereby independent variables are CB bills interest rates (INT_R) and inflation rate (INFL). In the second model (VECM_2), the dependent variable is the real GDP, also in the natural logarithm (LRGDP), whereas the independent variables are the same as in the previous model. For estimation of the model coefficients, as well as for the analysis in general, EViews 10 statistical software was used. 
Given the obvious seasonality in the data, all the variables were seasonally adjusted using the Census X12 method (additive approach). Also, in order to determine the level of integration of the variables, the Augmented Dickey-Fuller unit root test was employed, whereby the lag length was determined automatically, based on the Schwartz information criterion. Obtained results (Table 1) indicate that all the variables were non-stationary at level or integrated of 1 st order.

Table 1. Augmented Dickey-Fuller test (p-values) (Source: Authors' calculations)

\begin{tabular}{|c|c|c|c|c|}
\hline Variable & Included in the test equation & level & 1st diff. & $\begin{array}{c}\text { Order of } \\
\text { integration }\end{array}$ \\
\hline \multirow{3}{*}{ LRGDP } & Intercept & 0.9715 & 0.0000 & \multirow{3}{*}{$\mathrm{I}(1)$} \\
\hline & Trend and intercept & 0.6834 & 0.0000 & \\
\hline & None & 1.0000 & 0.0010 & \\
\hline \multirow{3}{*}{ LCREDIT } & Intercept & 0.6536 & 0.0389 & \multirow{3}{*}{$\mathrm{I}(1)$} \\
\hline & Trend and intercept & 0.8983 & 0.1079 & \\
\hline & None & 0.9894 & 0.0382 & \\
\hline \multirow{3}{*}{ INT_R } & Intercept & 0.2891 & 0.0028 & \multirow{3}{*}{$\mathrm{I}(1)$} \\
\hline & Trend and intercept & 0.0230 & 0.0104 & \\
\hline & None & 0.0035 & 0.0005 & \\
\hline \multirow{3}{*}{ INFL } & Intercept & 0.1655 & 0.0013 & \multirow{3}{*}{$\mathrm{I}(1)$} \\
\hline & Trend and intercept & 0.2461 & 0.0088 & \\
\hline & None & 0.2368 & 0.0001 & \\
\hline
\end{tabular}

As for the lag length in the estimated VECM models, based on the Akaike information criterion, the optimal lag length for the models (p) was 3. Given this optimal number of lags, the Johansen test indicated the presence of long term cointegration between the variables in both models, at 0.05 significance level, assuming intercept and no trend in the cointegration equation. Consequently, the theoretical VECM model was defined as follows:

$$
\begin{aligned}
\Delta Y_{i}=\beta_{0}+\alpha_{1}\left(Y_{i}\right. & \left.-\delta_{1} I N T_{-} R_{t-1}-\delta_{2} I N F L_{t-1}-\delta_{0}\right)+\beta_{1 p} \sum_{p=1}^{3} \Delta Y_{i_{t-p}}+\beta_{2 p} \sum_{p=1}^{3} \Delta I N T_{-} R_{t-p} \\
& +\beta_{3 p} \sum_{p=1}^{3} \Delta I N F L_{t-p}+u_{t}
\end{aligned}
$$

Where $Y_{i}$ represents LCREDIT and LRGDP in VECM_1 and VECM_2 models respectively; $\alpha_{1}$ is the cointegrating coefficient, which is assumed to be statistically significant and negative; $Y_{i}-$ $\delta_{1} I N T_{-} R_{t-1}-\delta_{2} I N F L_{t-1}-\delta_{0}$ is the cointegrating equation or the long-term relationship between variables; $\beta_{1 \mathrm{p}}, \beta_{2 \mathrm{p}}$ и $\beta_{3 \mathrm{p}}$ are the short-term causality coefficients; and $u_{t}$ is the error term. Given that the above theoretical model is essentially a VECM model with three endogenous variables, it consists of 3 model equations, one for each of the endogenous variables. However, for simplicity matters, (Eq.1) only presents the equation for the variables of interest (LCREDIT and LRGDP).

\section{Results}

Keeping in mind the monetary policy strategy in the North Macedonia, CB bills interest rates are maintained on a relatively high level. Dynamically analyzed, a decreasing trend was registered in the pre-crisis period (before 2008), followed by a simultaneous moderate increase in economic activity. On the other hand, the inflation rate is stable throughout the analyzed period, with small variations in the period immediately before the crisis. Thus, the inflation rate in the period 20002019 is $1.7 \%$ on average (in the pre-crisis period, it averaged around 3\%, and in the post-crisis period, around $1 \%$ ). At the same time, the GDP growth rate is $2.9 \%$ on average (3.5\% in the precrisis period and $2.4 \%$ in the post-crisis period). Regarding total lending, two periods can be clearly distinguished. One is the period before the global economic crisis (2002-2008) when a 
trend of a significant increase in credit growth was registered. Namely, in 2008 credit growth reached $40 \%$ on an annual basis, which corresponds to the relatively higher GDP growth rates in spite of the still relatively high CB bills interest rates in this period. The second period is the period after the crisis (2010-2019) when a significant decrease in credit growth was registered. The average credit growth in this second period is $6 \%$, which reflects the increased credit risk and the prudent approach of the banks in conditions of weaker economic activity. In addition, this also reflects the stricter regulatory requirements established by the NBRNM.

In line with the theoretical and empirical literature, $\mathrm{CB}$ bills interest rates and inflation rate in North Macedonia have a negative linear relationship with total lending and real GDP. However, based on the estimated correlation coefficients (Table 2), one can easily notice that CB bills interest rates have a far stronger negative linear relationship with the total lending and real GDP in North Macedonia than the inflation rate.

Table 2. Pearson's correlation coefficients between dependent and independent variables (Source: Authors' calculations)

\begin{tabular}{|c|c|c|}
\hline & LCREDIT & LRGDP \\
\hline INT_R & -0.86 & -0.86 \\
\hline INFL & -0.26 & -0.31 \\
\hline
\end{tabular}

Regarding the estimated models, a summary of the obtained results for both VECM_1 and VECM_2 models is presented in Table 3. Although overall, both estimated models are statistically significant (probability for the F-statistics < 0.05), the VECM_1 model has a far better model fit than the VECM_2 model. Namely, the adjusted R-squared coefficient in the VECM_1 model is 0.68 , which means that the model explains around $70 \%$ of the variations of the dependent variable (LCREDIT), as opposed to 0.13 , or $13 \%$ of the variations of the dependent variable in VECM_2 model (LRGDP). According to Ferguson (2009), the minimum acceptable effect size is $\mathrm{F}=2$ is, whereas F > 4 indicates a strong effect size. In addition, unlike the VECM_1 model, VECM_2 violates the assumption of no serial correlation in the residuals $(\mathrm{LM}=19.96)$. On the other hand, heteroskedasticity is not a problem in both estimated models. Furthermore, both VECM models meet the stationarity requirements since there are two inverse roots in each of the models.

Table 3. Summary for the estimated VECM_1 and VECM_2 models (Source: Author's calculation)

\begin{tabular}{|c|c|c|}
\hline Dependent variable & $\begin{array}{c}\text { VECM_1: } \\
\text { D(LCREDIT) }\end{array}$ & $\begin{array}{c}\text { VECM_2: } \\
\text { D(LRGDP) }\end{array}$ \\
\hline R-squared & 0.72 & 0.24 \\
\hline Adjusted R-squared & 0.68 & 0.13 \\
\hline F-statistics & 16.9 & 0.1 \\
\hline Prob. F-statistics & 0.000 & 19.96 \\
\hline $\begin{array}{c}\text { Breusch-Godfrey serial correlation LM } \\
\text { test }\end{array}$ & $0.057^{*}$ & $10.19^{*}$ \\
\hline White test for heteroskedasticity & $13.508^{*}$ & . \\
\hline
\end{tabular}

Note: The coefficients marked with * are statistically insignificant at 0.05 significance level

Regarding the mutual relationship between the endogenous variables, conducted GrangerCausality test shows that CB bills interest rates do not cause total lending, nor real GDP, in the short run. On the contrary, the inflation rate seems to have a statistically significant short-term impact on both of these variables. Table 4 presents the Chi-square test statistics of the Grangercausality test for both models. As one can notice, the null hypothesis of no causal relationship cannot be rejected for the case of the CB bills interest rates, whereas for the inflation rate, it can be rejected at a 0.05 significance level. 
Table 4. Granger-Causality test for VECM_1 and VECM_2 models (test statistics) (Source: Authors' calculation)

\begin{tabular}{|c|c|c|}
\hline Variable & VECM_1: D(LCREDIT) & VECM_2: D(LRGDP) \\
\hline D(INT_R $)$ & $4.1 *$ & $2.3 *$ \\
\hline D(INFL) & 10.8 & 9.1 \\
\hline
\end{tabular}

Note: The coefficients marked with $*$ are statistically insignificant at 0.05 significance level

Regarding the long-run relationship, as one can notice from the results presented in Table 5, the estimated cointegration coefficients in both models are negative and statistically significant at a 0.05 significance level (Hendry, 2003). This means that the models tend to converge in some long-run equilibrium level, with the speed of adjustment of 0.02 and 0.03 respectively for VECM_1 and VECM_2 models. As opposed to the results for the short-run relationship, the inflation rate does not have a statistically significant long-term impact on total lending nor on the real GDP in North Macedonia. On the other hand, CB bills interest rates negatively affect both of these variables in the long run, whereby the impact is much stronger on the total lending $(-0.24)$ compared to the real GDP $(-0.06)$.

Table 5. Cointegration coefficients (long-run relationship) for both estimated models (Source: Authors' calculation)

\begin{tabular}{|c|c|c|}
\hline Variable & VECM_1: D(LCREDIT) & VECM_2: D(LRGDP) \\
\hline $\begin{array}{c}\text { Cointegration } \\
\text { coefficient }\end{array}$ & -0.02 & -0.03 \\
\hline C & 14.2 & 25.6 \\
\hline INT_R(-1) & -0.24 & -0.06 \\
\hline INFL(-1) & $0.06^{*}$ & $-0.02 *$ \\
\hline
\end{tabular}

Note: The coefficients marked with $*$ are statistically insignificant at 0.05 significance level

The above long-run relationship can be visualized through the accumulated impulse responses of the total lending and real GDP to a shock of one standard deviation in the CB bills interest rates and the inflation rate. As can be noticed from Figure 1, there seems to be a certain time lag in the long-run relationship, whereby the impulse responses in both cases show an obvious tendency to increase over time.
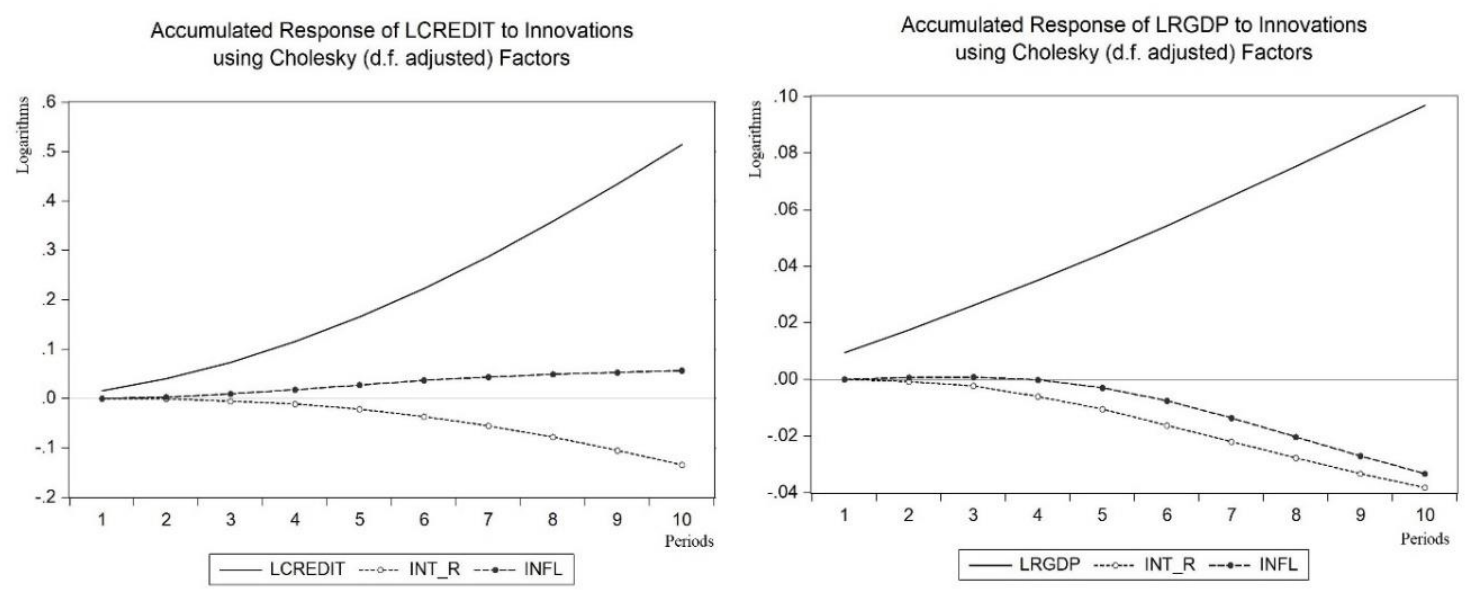

Figure 1. Accumulated impulse responses of total lending (left) and real GDP (right) (Source: Authors' illustration)

However, the $\mathrm{CB}$ bills interest rates explain as much as $8.4 \%$ of the variations of the total lending and $14.4 \%$ of the variations of the real GDP in North Macedonia (Figure 2). On the other hand, the inflation rate has a far smaller impact when it comes to the total lending (explains $1.2 \%$ of the 
total variations), whereas regarding the real GDP, it explains almost $15 \%$, almost the same as the $\mathrm{CB}$ bills interest rates.
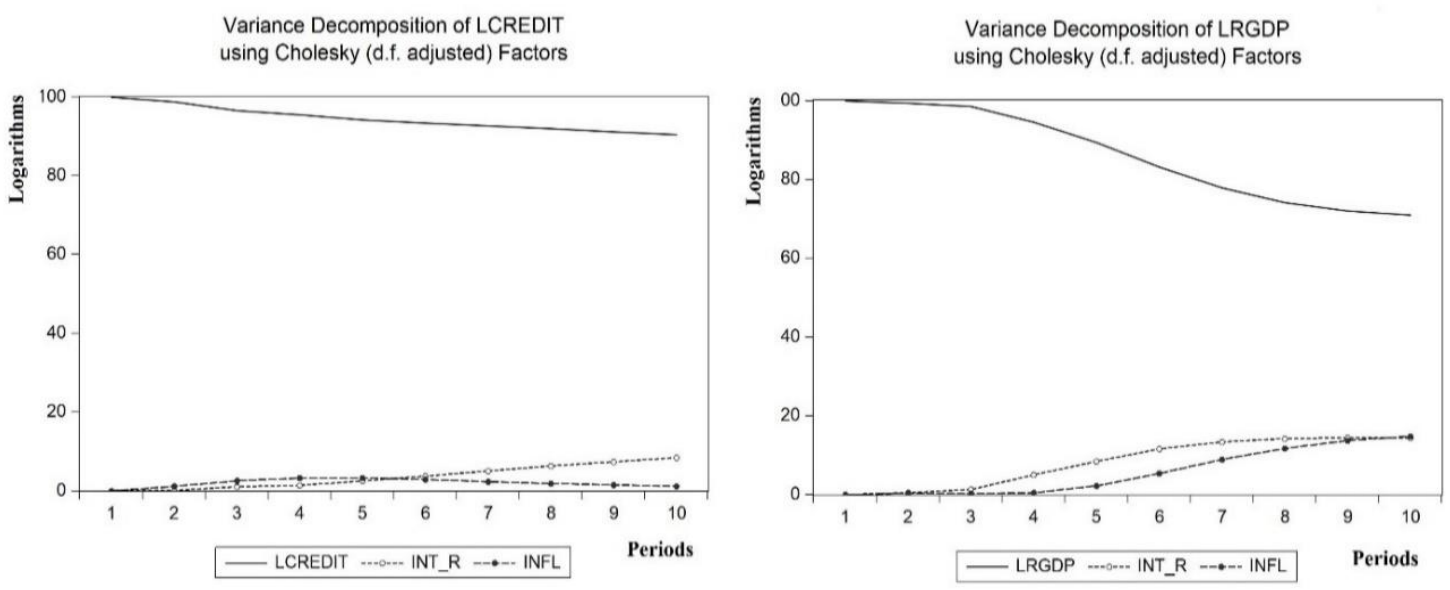

Figure 2. Variance decomposition of total lending (left) and real GDP (right) (Source: Authors' illustration)

Conducted analysis shows the negative long-term impact of the $\mathrm{CB}$ bills interest rates on lending and real GDP in RNM. The inflation rate, in the long run, does not have a statistically significant impact.

\section{Conclusions}

The role of the central banks and financial markets, through different channels of action, are particularly relevant for the countries' economic activity, especially in small and open economies characterized by banking systems with excess liquidity. The monetary policy strategy in conditions of structural excess liquidity in the country determines the main instrument of the auction of the central bank treasury bills. Therefore, the interest rates achieved at the treasury bills auctions are considered to be the basic interest rate of the National Bank. Banks, on the other hand, consider CB bills as an alternative instrument for placing their assets and receiving monetary signals that have an impact on interest rates on lending and deposits.

From the methodological point of view, the analysis is based on the estimation of two different VECM models, one for the total lending and one for the real GDP, whereby CB bills interest rates and inflation rate are taken as independent variables. The analysis also includes Granger causality and Johansen cointegration tests for the short-run and the long-run relationship, respectively, as well as estimation of the impulse response function and variance decomposition.

Based on the conducted empirical analysis for the case of the Republic of North Macedonia, one can conclude that interest rates on CB bills, as passive interest rates, do not have a statistically significant short-term impact on total lending as well as on the country's real GDP. On the other hand, results show a statistically significant, negative long-term impact of the CB bills interest rates on both total lending and real GDP in North Macedonia. This implies that central banks should reduce the interbank rate when faced with crises that cause liquidity disparities between banks, and the failure to reduce interest rates during the crisis disrupts financial stability, which increases the risk of banks operating. As for the impact of the inflation rate, the research provides opposite results. Namely, the inflation rate has a statistically significant, negative, short-term impact on total lending and real GDP in North Macedonia, but no long-term impact.

The results of the paper open the possibility for further research, given that Greenwald and Stiglitz (2003) confirm that lending is not only related to the CB bills interest rates, but also to their net worth, level of risk, level of the existing asset portfolio and regulatory constraints. 


\section{References}

Akosah N.K. (2015). Is the Monetary Policy Rate Effective? Recent Evidence from Ghana. IHEID Working Paper 14-2015. Economics Section, The Graduate Institute of International Studies. https://doi.org/10.1080/23322039.2021.1966918

Amidu Mohammed. (2006). The Link Between Monetary Policy and Banks Lending Behaviour: The Ghanaian Case. Banks and Bank Systems, 1(4). [Accessed 17.11.2021]. Available from Internet: http://ugspace.ug.edu.gh/handle/123456789/28789

Bambujijumugisha, Theoneste. (2016). The Relationship between GDP and Money Demand in Rwanda. [Accessed 30.09.2021]. http://dx.doi.org/10.2139/ssrn.2973088

Barnett, W. \& Su, L. (2019). "Monetary aggregation theory and nominal GDP targeting". Int. J. Business and Globalisation, 22(4), pp. 490-505. https://doi.org/10.1504/IJBG.2019.10021965

Calza, Alessandro \& Gartner, Christine \& Sousa, João, 2001. "Modelling the demand for loans to the private sector in the euro area," Working Paper Series 55, European Central Bank. https://doi.org/10.1080/00036840210161837

Capie, Forrest and Wood, Geoffrey E. (2016). Central Bank Governance: Evolution, Goals, and Crises, BAFFI CAREFIN Centre Research Paper, No. 2016-31. http://dx.doi.org/10.2139/ssrn.2815826

Chaitipa, P., Chokethaworn, K., Chaiboonsri, C. \& Monekeo, (2015). "Money Supply Influencing on Economic Growth-wide Phenomena of AEC Open Region", Procedia Economics and Finance, Volume 24, pp. 108-115. https://doi.org/10.1016/S2212-5671(15)00626-7

Chandrashekar, R., Sampath, T. \& Chittedi, K. R. (2018). "Financial development, trade openness and growth in India". Theoretical and Applied Economics, Spring, XXV, No. 1(614), pp. 113-124. [Accessed 03.10.2021]. Available from Internet: http://store.ectap.ro/articole/1323.pdf

Ehigiamusoe K.U., Guptan V., Narayanan S. (2019). The effects of income and inflation on financial development: Evidence from heterogeneous panels, Economics Discussion Papers, No 2019-11, Kiel Institute for the World Economy. [Accessed 06.10.2021]. Available from Internet: http://hdl.handle.net/10419/193174

Ferguson, C. J. (2009). An effect size primer: A guide for clinicians and researchers. Professional Psychology: Research and Practice, 40(5), pp. 532-538. https://doi.org/10.1037/a0015808

Freixas, X., Martin, A., \& Skeie, D. (2011). Bank Liquidity, Interbank Markets, and Monetary Policy. The Review of Financial Studies, Society for Financial Studies, Vol. 24(8), pp. 2656-2692. https://doi.org/10.1093/rfs/hhr018

Gigineishvili, N. (2011). Determinants of Interest Rate Pass-Through: Do Macroeconomic Conditions and Financial Market Structure Matter? IMF Working Papers, 11(176), [Accessed 15.10.2021]. Available from Internet: https://ssrn.com/abstract=1899577

Gonpot P.N., Allybokus M., Sookia N.H., Gujadhur P. (2010). A Vector Autoregressive (VAR) Approach to the Credit Channel for the Monetary Transmission Mechanism in Mauritius. University of Mauritius Research Journal, Volume 16, No. 1, pp. 168-195. [Accessed 20.10.2021]. Available from Internet: https://www.ajol.info/index.php/umrj/article/view/130798

Greenwald B. \& Stiglitz J. E. (2003). Towards a New Paradigm in Monetary Economics. Cambridge University Press. https://doi.org/10.1017/CBO9780511615207

Hendry, D. (2003). J. Denis Sargan and the origins of LSE Econometric methodology. Econometric Theory, 19(3), pp. 457-480. https://doi.org/10.1017/S0266466603193061

Ireland, Peter N. (2006). The monetary transmission mechanism. Working Papers, No. 06-1, Federal Reserve Bank of Boston, Boston, MA. http://dx.doi.org/10.2139/ssrn.887524

Jovanovic, Branimir; Krstevska, Aneta; Popovska-Kamnar, Neda. (2015). Can Monetary Policy Affect Economic Activity under Surplus Liquidity? Some Evidence from Macedonia, Working Paper, No. 2015 03, National Bank of the Republic of Macedonia, Skopje. [Accessed 18.11.2021]. Available from Internet: http://hdl.handle.net/10419/173712

Kabashi, Rilind; Suleva, Katerina. (2016). "Loan Supply Shocks in Macedonia: A Bayesian SVAR Approach with Sign Restrictions". Croatian Economic Survey, vol. 18(1), pp. 5-33. https://doi.org/10.15179/ces.18.1.1 
Karimo, T.M., \& Ogbonna, O.E. (2017). Financial Deepening and Economic Growth Nexus in Nigeria: Supply-Leading or $\quad$ Demand-Following? Economies, $\quad 5(1): 4, \quad$ pp. $\quad 1-18$. https://doi.org/10.3390/economies5010004

Levine, R. (2004). Finance and Growth: Theory and Evidence. NBER Working Papers 10766, National Bureau of Economic Research, Inc. https://doi.org/10.1016/S1574-0684(05)01012-9

Nyawata, O., (2013). Treasury Bills and/or Central Bank Bills for Absorbing Surplus Liquidity: The Main Considerations. Journal of International Commerce, Economics and Policy (JICEP), Vol. 4(02), pp. 1-32. https://doi.org/10.1142/S1793993313500117

Olofinlade, Oluwapelumi Samuel; Oloyede, Adebayo John; Oke, Ojo Michael. (2020). The Effects of Monetary Policy on Bank Lending and Economic Performance in Nigeria, ACTA UNIVERSITATIS DANUBIUS, Vol 16, no 2, pp. 150-159. ISSN: 2065-0175. [Accessed 16.11.2021]. Available from Internet: https://dj.univ-danubius.ro/index.php/AUDOE/article/view/215/710

Schumpeter, J.A. (2017). The Theory of Economic Development: An Inquiry into Profits, Capita I, Credit, Interest, and the Business Cycle (1st ed.). Routledge. https://doi.org/10.4324/9781315135564

Shijaku, Gerti \& Kalluci, Irini. (2013). "Determinants of bank credit to the private sector: The case of Albania," MPRA Paper 79092, University Library of Munich, Germany. [Accessed 20.10.2021]. Available from Internet: https://mpra.ub.uni-muenchen.de/79092/

Sultana, N. (2018). "Impacts of money supply, inflation rate and interest rate on economic growth: A case of Bangladesh". JETIR, 5(10). https://doi.org/10.1729/Journal.18824

Willems, T. (2018). What Do Monetary Contractions Do? Evidence from an Algorithmic Identification Procedure. IMF Working Papers, 18(211). https://doi.org/10.5089/9781484378229.001 